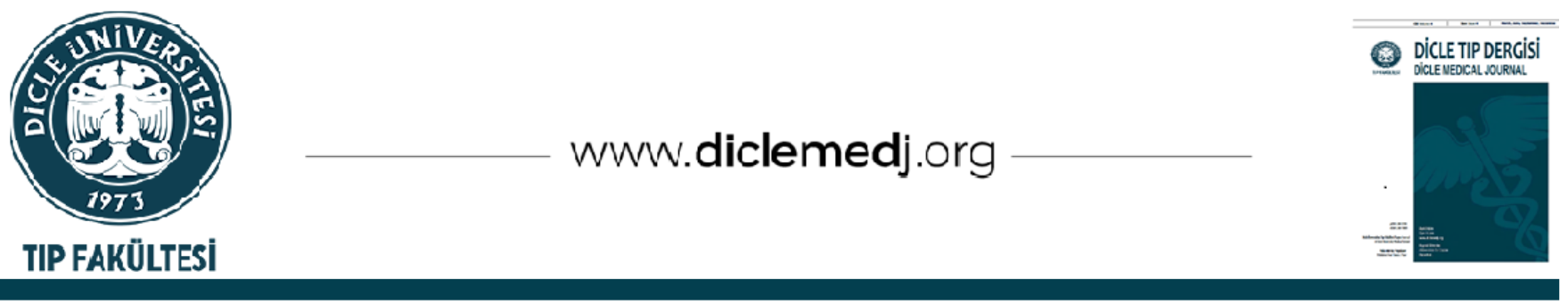

Original Article / Özgün Araştırma

\title{
Which one Affects More to Clinical and Radiological Outcomes in Pediatric Calcaneus Fractures? Is the Severity of Trauma or the Applied Surgical Technique?
}

\author{
Seyhmus Yigit ${ }^{i}{ }_{1}$, Emin Ozkul ${ }^{D_{1}}$, Ramazan Atic ${ }^{D_{1}}$, Veysel Kandemir ${ }^{D_{1}}$, Ali Turgut ${ }^{D_{2}}$, \\ Azad Yıldırım ${ }^{\mathrm{iD}_{3}}$ \\ 1 Department of Orthopaedic Surgery, Dicle University, Faculty of Medicine, Diyarbakır, Turkey \\ 2 Department of Orthopaedics and Traumatology, Tepecik Training and Research Hospital, İzmir, Turkey
}

3 Department of Orthopaedics and Traumatology, Gazi Yaşargil Training and Research Hospital, Diyarbakır, Turkey

Received: 09.08.2021; Revised: 16.09.2021; Accepted: 22.09.2021

\begin{abstract}
Objective: The aim of our study is to evaluate the clinical and radiographic results of pediatric calcaneus fractures treated in our hospital in terms of age, treatment techniques and trauma severity and to compare with the literature

Methods: This is a retrospective study conducted on 22 pediatric patients (28 calcaneus fractures) treated with surgery for calcaneus fractures in our hospital from March 2005 to January 2020. There were seven patients (patients between 3 and 6 years old) in group 1 and 15 patients (between 7 and 16 years old) in group 2.

Results: 17 fractures were treated with the CRPP technique, 11 fractures were treated with the ORIF technique. The mean age was 11.4 months (range 3-16). Average follow-up time 81.54 months (range 12-156). There is a significant relationship between age and CRPP(p:0.000), but not with ORIF(p:0.10). The most important result of our study is that there is no significant difference between AOFAS scores with CRPP and ORIF techniques (P: 0.167 and p: 0.20, respectively). The second most important result in our study was that there was a significant relationship between Essex Lopresti and Sanders classification to AOFAS score(p: 0.013 in both.).

Conclusion : Immature calcaneus fractures are rare, and those without anatomical reduction, as in adults, have poor results. In pediatric calcaneus fractures, fragmentation due to the severity of trauma, cartilage damage, cancellous bone loss and their consequence may cause circulatory disorders between the fracture parts. As a result, post-traumatic arthritis may develop even if anatomical reduction is made. The most important thing that determines the result in pediatric calcaneus fractures is how high energy the fracture occurs rather than the surgical technique to be chosen.
\end{abstract}

Keywords: Pediatric calcaneus; fracture; posttraumatic arthritis; internal fixation; percutaneous pinning

DOI: 10.5798/dicletip.1030393

Correspondence / Yazışma Adresi: Seyhmus Yigit, Department of Orthopaedic Surgery, Dicle University, Faculty of Medicine, Diyarbakır, Turkey e-mail: dryigit8884@hotmail.com 


\section{Pediatrik Kalkaneus Kırıklarında Hangisi Klinik ve Radyolojik Sonuçları Daha Çok Etkiler? Travmanın Şiddeti mi Uygulanan Cerrahi Teknik mi?}

Öz

Amaç: Çalışmamızın amacı hastanemizde tedavi edilen çocuk kalkaneus kırıklarının klinik ve radyografik sonuçlarını yaş, tedavi teknikleri ve travma şiddeti açısından değerlendirmek ve literatürle karşılaștırmaktır.

Yöntemler: Mart 2005 ile Ocak 2020 tarihleri arasında hastanemizde kalkaneus kırı̆̆ı nedeniyle ameliyat edilen 22 pediatrik hasta (28 kalkaneus kırığı) üzerinde yürütülen retrospektif bir çalışmadır. grup 1'de yedi hasta (3-6 yaş arası hastalar) ve grup 2'de 15 hasta (7-16 yaş arası)

Bulgular: 17 kırık CRPP tekniği ile, 11 kırık ORIF tekniği ile tedavi edildi. Ortalama yaş 11.4 ay (dağılım 3-16) idi.Ortalama takip süresi 81,54 ay (12-156). Yaș ile CRPP(p:0.000) arasında anlamlı bir ilişki vardır, ancak ORIF(p:0.10) ile değildir. Çalışmamızın en önemli sonucu, CRPP ve ORIF teknikleri ile AOFAS puanları arasında anlamlı bir fark olmamasıdır (sırasıyla P: 0.167 ve p: 0.20 ). Çalışmamızdaki en önemli ikinci sonuç ise Essex Lopresti ve Sanders sınıflaması ile AOFAS skoru arasında anlamlı bir ilişki olduğuydu (her ikisinde de p: 0,013).

Sonuç : İmmatür kalkaneus kırıkları nadirdir ve erişkinlerde olduğu gibi anatomik redüksiyon yapılmayanlarda kötü sonuçlar vardır. Pediatrik kalkaneus kırıklarında travmanın şiddetine bağlı olarak parçalanma, kıkırdak hasarı, süngerimsi kemik kaybı ve bunların sonucu olarak kırık parçalar arasında dolaşım bozukluklarına neden olabilir. Sonuç olarak anatomik redüksiyon yapılsa bile travma sonrası artrit gelişebilir. Pediatrik kalkaneus kırıklarında sonucu belirleyen en önemli şey, seçilecek cerrahi teknikten ziyade kırığın ne kadar yüksek enerj ile oluştuğudur.

Anahtar kelimeler: Pediatrik kalkaneus; kırık; travma sonrası artrit; internal fiksasyon; perkütan pinleme.

\section{INTRODUCTION}

Calcaneus fractures are rare in children, and calcaneus fractures are misdiagnosed because of the high cartilage and low bone ratio ${ }^{1}$. The incidence of calcaneus fractures is approximately $2 \%$ of adult fractures ${ }^{2}$ and approximately 1 in 100,000 of pediatric fractures $^{3}$. In the literature, delayed diagnosis rate with pediatric calcaneus fractures has been reported as $27-55 \%{ }^{4}$. In the past, scintigraphy was used when the diagnosis of fracture was not made with plain X-rays ${ }^{5}$, but now if a fracture is suspected, magnet resonance imaging (MRI) is used for diagnosis².

Falling from height is the most common cause of calcaneus fractures ${ }^{6,7}$. Axial force pushes the talus against the calcaneus, causing the fracture.6 Often the degree of fragmentation appears to be less in children, despite the higher severity of trauma than adults ${ }^{7}$. Traffic accidents are the second most common cause of calcaneus fractures ${ }^{6,7}$. Other causes are kitchen or garden accidents and direct bumps, which are more common in children than adults ${ }^{8}$.
Treatment of pediatric calcaneus fractures is still controversial. In the literature, long-term outcomes of conservative treatment have been shown to be sufficient in pediatric calcaneus fractures without or with minimal joint involvement ${ }^{9}$. Results were less successful in severely displaced intra-articular fractures treated conservatively ${ }^{10}$. Some authors did not find any loss of function when they treated both intra-articular and extra-articular fractures non-operatively ${ }^{4,11}$. Recently, surgical treatment with open reduction and internal fixation has been performed more and more ${ }^{6}$.

The aim of our study is to evaluate the clinical and radiographic outcomes of pediatric calcaneus fractures treated in our hospital in terms of age, treatment techniques and trauma severity and to compare with the literature. Our hypothesis is that if the severity of the initial calcaneus fracture and general body trauma is high, the clinical outcome will be poor, and the surgical treatment technique performed does not affect the result. 


\section{METODS}

This is a retrospective study conducted on 22 pediatric patients ( 28 calcaneus fractures) treated for calcaneus fractures in our hospital from March 2005 to January 2020. There were seven patients (patients between 3 and 6 years old) in group 1 and 15 patients (between 7 and 16 years old) in group 2. The grouping was made not according to the injury severity scores or the type of surgical treatment applied, but by considering the age of formation of the secondary ossification center of the calcaneus in children ${ }^{2}$. Patient data are fracture type, age, gender, duration of surgery, additional injuries, surgical technique, pre- and postoperative Gissen and Bohler angles, and American Orthopedic Foot an Ankle Score (AOFAS). Patients with open calcaneus physis and primary surgical treatment were included in the study. Incomplete patient data and patients with a history of previous joint surgical treatment for any reason (trauma, cancer, and infection) were excluded from the study. Due to inadequate records, or lost to follow-up, 7 patients were excluded from the study.

In our hospital, calcaneus fractures are treated surgically with open reduction internal plate fixation (ORIF) with a modified Letournel approach $^{12}$ (Fig 1), and with closed reduction and percutaneous pinning (CRPP) in Westhues's ${ }^{13}$ and Wondrák's14 procedures (Fig 2). The surgical treatment to be applied could not be directly performed according to the Sanders or Essex lopresti classification. The surgical technique to be performed varies according to the general condition of the patient, age, soft tissue pathology in the ankle and the presence of multiple trauma. For postoperative immobilization, a short leg splint was applied and kept in elevation for up to 10 days. Antibiotic treatment was prolonged according to the general condition of the patient, but it was continued for three days as prophylactic. Sutures were removed in two weeks and if the soft tissue reduced edema, the splint was removed and passive joint motion were initiated. If the callus tissue is sufficient in the Xray, partial weight bearing were started after the 6th week. K-wires were removed at 8th week if bone union occurred in patients treated with CRPP.

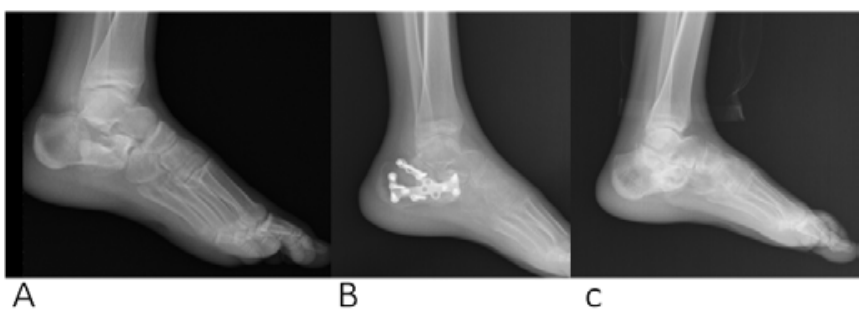

Figure 1: A 15-year-old male patient with a right calcaneus fracture underwent surgical treatment with open reduction internal plate fixation. Radiographs: a) preoperative, b) postoperative, and c) two years after surgery

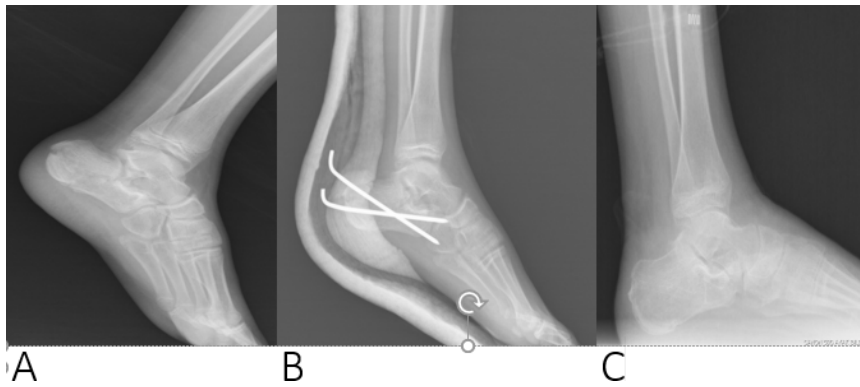

Figure 2: A 14-year-old male patient with a right calcaneus fracture underwent surgical treatment closed reduction and percutaneous pinning. Radiographs: a) preoperative, b) postoperative, and c) one year after surgery

Fractures were classified according to EssexLopresti classification on X-ray which modified by Schmit and Weiner ${ }^{4}$, and Sanders classification according to CT imaging ${ }^{15}$. The clinical outcome was made using the American Orthopedic Foot and Ankle Association (AOFAS) score ${ }^{16}$. Sanders' posttraumatic arthritis classification was used for post-traumatic arthritis ${ }^{15}$.

The study was approved by the Ethics Review Committee of our faculty (224/09.04.2021). All data were obtained without a personal

identification document and made in accordance with the Declaration of Helsinki regulation.

We preformed analysis using standard statistical computer software, that is, Statistical Package for Social Sciences (SPSS, version 24). Numerical data obtained in the study are shown as mean \pm SD, (min-max), categorical data as frequency and percentage values. Kolmogorov-Smirnov test, Chisquare test and Student test were used to 
compare categorical data. Data were compared by using P-value of $<0.05$ was considered to be statistically significant.

\section{RESULTS}

Twenty eight calcaneus fractures in twenty two children were treated surgically in our study. 17 fractures were treated with the closed reduction and percutaneous pinning technique, 11 fractures were treated with the open reduction internal plate fixation technique. There was no significant difference between the groups (p: 0.09). There were seven girls and fifteen boys. Group 1 had 2 female and 5 male patients, and group 2 had 5 female and 10 male patients(p:0.891). The day of operation after the hospitalization was 3.5 days. (range 1-15). The mean age was 11.4 years (range 3-16). Average follow-up time 81.54 months (range 12-156). The calcaneus fracture resulted from falling from height( $>2$ metres) in fourteen patients, traffic accident in four patients, and simple fall $(<2$ metres) in four patients. There was Table I: Data of patients no significant difference between the groups (p: 0.682). Only 3 patients had isolated closed calcaneus fractures. The patients had 10 tibia fractures, 5 femur fractures, 5 vertebral fractures, 5 foot bone's fractures, 2 orbital fractures, 3 nasal fractures, 2 pelvis fractures, and 3 hand or wrist fractures, along with calcaneus fractures. Nine patients had open calcaneus fractures and 5 patients had open fractures in other bones. ORIF surgical treatment was not performed in any of the open calcaneus fractures due to the risk of osteomyelitis. The mean preoperative Gissane angle was $141.5^{\circ}$ (range $106^{\circ}-170^{\circ}$ ) and the average Böhler angle was $15.9^{\circ}$ (range $-15^{\circ}$ $+37^{\circ}$ ) While there was no significant difference between the groups with the Gissane angle (p:0.092), there was a significant difference between the groups with the Böhler angle(p:0.00). Preoperative angle measurements were made by 2 senior authors simultaneously with the digital device (Table 1).

\begin{tabular}{|c|c|c|c|c|c|c|c|c|}
\hline & Sex & Age & Side & Trauma & \begin{tabular}{|l|} 
Essex-Lopresti \\
Classification \\
\end{tabular} & Sanders Classification & Treatment & AOFAS Score \\
\hline 1 & M & 16 & $\mathrm{R}$ & $\mathrm{FH}$ & TT & IIIb, & CRPP & R70, \\
\hline 2 & $\mathrm{~F}$ & 15 & B & SF & $\mathrm{JD}$ & R IIIc, L IIIc & CRPP & R66, L68 \\
\hline 3 & $\mathrm{~F}$ & 16 & B & $\mathrm{FH}$ & JD & R IIIc, L IV & CRPP & R80, L66 \\
\hline 4 & $\mathrm{M}$ & 11 & $\mathrm{~L}$ & SF & 2 & IIa & CRPP & 72 \\
\hline 5 & $M$ & 4 & $\mathrm{~L}$ & FH & TT & IIIa & CRPP & 86 \\
\hline 6 & $\mathrm{M}$ & 14 & $\mathrm{~L}$ & $\mathrm{FH}$ & TT & $\mathrm{IIb}$ & ORIF & 72 \\
\hline 7 & M & 6 & $\mathrm{R}$ & SF & TT & $\mathrm{IIb}$ & CRPP & 88 \\
\hline 8 & $\mathrm{M}$ & 15 & $\mathrm{~L}$ & $\mathrm{TA}$ & $\mathrm{JD}$ & IV & ORIF & 66 \\
\hline 9 & $\mathrm{~F}$ & 6 & $\mathrm{~L}$ & $\mathrm{TA}$ & $J \mathrm{D}$ & IV & CRPP & 66 \\
\hline 10 & M & 3 & $\mathrm{~L}$ & $\mathrm{FH}$ & TT & IIb & CRPP & 95 \\
\hline 11 & $M$ & 4 & $\mathrm{R}$ & FH & 3 & IIa & CRPP & 88 \\
\hline 12 & $\mathrm{M}$ & 14 & $\mathrm{~L}$ & $\mathrm{FH}$ & TT & IIIa & ORIF & L62 \\
\hline 13 & $\mathrm{~F}$ & 15 & $\mathrm{~L}$ & $\mathrm{FH}$ & 3 & IIb & ORIF & 72 \\
\hline 14 & $\mathrm{M}$ & 14 & $\mathrm{R}$ & TA & 4 & IIIIc & CRPP & 88 \\
\hline 15 & $\mathrm{~F}$ & 14 & B & $\mathrm{FH}$ & JD & R IIIc, L IIIc & ORIF & R70 ,L72 \\
\hline 16 & M & 15 & B & $\mathrm{FH}$ & R 4, L JD & R IIb, L IV & ORIF & R82, L64 \\
\hline 17 & $M$ & 14 & B & $\mathrm{FH}$ & R 3, L JD & R IIb, LIV & ORIF & R66, L68 \\
\hline 18 & M & 13 & $\mathrm{R}$ & SF & 3 & II & ORIF & R70 \\
\hline 19 & M & 15 & $\mathrm{~L}$ & FH & JD & IIIIC & ORFF & 74 \\
\hline 20 & M & 6 & B & FH & R JD, L 3 & R IIIc, LII & CRPP & R82, L84 \\
\hline 21 & $F$ & 5 & $\mathrm{~L}$ & $\mathrm{TA}$ & TT & II & CRPP & 88 \\
\hline 22 & $\mathrm{~F}$ & 16 & $\mathrm{~L}$ & $\mathrm{FH}$ & TT & IV & CRPP & L71 \\
\hline
\end{tabular}

$M$, male; $F$, female; $R$, right; $L$, left; B, bilateral; $m$, meters; SF,simple falling; FH, falling from height; TA, traffic accident; JD, joint- depression ;TT, tongue type; ORIF, open reduction internal plate fixation; CRPP, closed reduction and percutaneous pinning 
A significant correlation was found between the day of operation after the hospitalization and the AOFAS score results ( $p$ : 0.00). When we compare age and surgical treatment, there is a significant relationship between age and CRPP (p: 0.00), but not with ORIF (p: 0.10) (Table 2). When we look at the relationship between the patient with additional injury other than calcaneus fracture and the choice of surgical technique, there was a significant relationship between CRPP and ORIF selection (p.0.023). In addition, there was a significant difference between the Essex Lopresti classification and the choice of CRPP or ORIF surgery (p: 0.033), and there was a significant difference between the Sanders classification and the ORIF surgical technique selection (p: 0.00). In our study, when the effect of Gissane angle and Böhler angle on CRPP and ORIF technique selection was examined, no significant difference was found between them (P: 0.20 and p: 0.08, respectively)(Figure 3 ).

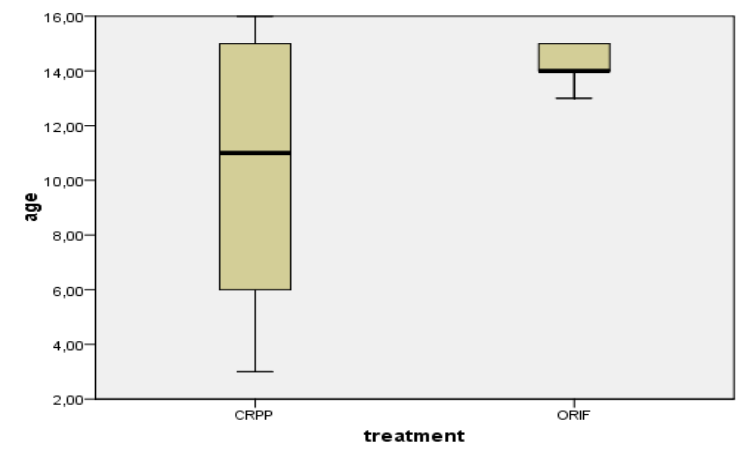

Figure 3: The relationship of age with CRPP and ORIF techniques

Our AOFAS score mean was 76.2 (range 62-95). In our study, there were 14 fair, 13 good and 1 excellent results according to the AOFAS score. The most important result of our study is that when we look at the relationship between AOFAS scores and CRPP and ORIF techniques, no significant difference was found between them (P: 0.167 and p: 0.20, respectively) (Figure 4).

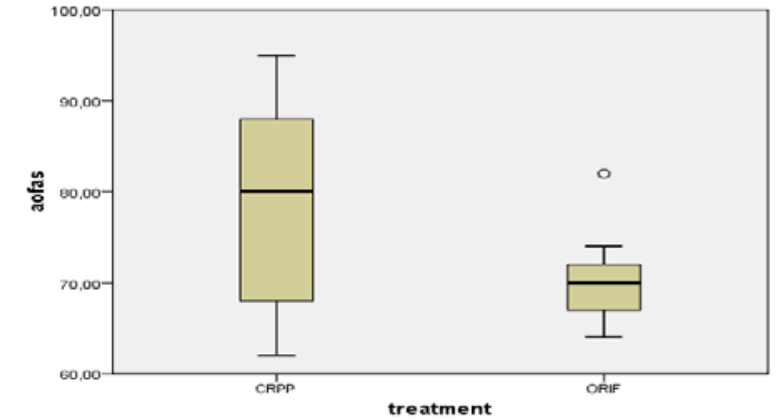

Figure 4: The relationship between AOFAS scores to CRPP and ORIF techniques

The second most important result in our study was that there was a significant relationship between Essex Lopresti and Sanders classification to AOFAS score. As the severity of the fracture in the calcaneus increases, the functional result gets worse according to the AOFAS score (p: 0.013 in both). There were 13 right and 19 left calcaneus fractures. There was no significant relationship between the side of the fracture and the AOFAS score (p: 0.207).

Approximately $75 \%$ of our patients had posttraumatic arthritis that correlated with the Sanders score on X-ray.15 There was a significant relationship with the Sanders classification (p: 0.027). Almost all Type III and Type IV patients had post-traumatic arthritis. In group 1, 3 patients had superficial infection and they treated with antibiotics and daily dressing. Superficial infection developed in four patients treated with CRPP in group 2. They were treated with antibiotics and daily dressings. Superficial skin problems developed in three patients treated with ORIF and deep skin necrosis developed in 1 patient. Skin graft was applied to the patient. In group 2, reduction loss requiring revision surgery occurred in one patient treated with ORIF.

\section{DISCUSSION}

In pediatric calcaneus fractures, surgery should be performed as soon as the general condition of the patient and the soft tissues around the 
fracture allow. In our study, clinical and radiological results were better in patients who were operated on early after fracture. We attribute this to early surgery preventing avascular necrosis. However, sometimes, even if we do the ideal treatment at the ideal time, the result is not always good. The important result of this study is that surgical treatment with CRPP or ORIF does not directly affect the functional outcome in calcaneus fractures according to the AOFAS score. The severity of trauma in the initial calcaneus fracture is the most important factor determining the outcome. The more fragmentation in the calcaneus, the worse the functional results.

Calcaneus is the first ossified bone among the tarsal bones. There is a primary ossification centre at the time of birth. A secondary ossification centre is formed at the age of 6-8 and completes its development around the age of $14-16^{2}$. Until the skeletal maturation is complete, the calcaneus is covered with cartilage $^{17}$. In the past, there were opinions that the articular surface of the subtalar joint could be reshaped to correct the deformity as the child got older ${ }^{18}$. It was observed that calcaneus fractures, which were treated conservatively and where Böhler's angle was severely reduced, had permanent deformity and the calcaneus was not always reshaped ${ }^{9}$. There are not many studies in the literature on the treatment of skeletally immature displaced intra-articular calcaneus fractures ${ }^{19}$. Schmidt and Weiner found that $10 \%$ of calcaneus fractures below the age of 7 are intra-articular, this rate is $40 \%$ between the ages of 7-14 and 70\% in those aged 15 years $^{4}$. In contrast, Schantz and Rasmussen found that intra-articular fractures were more common at younger ages ${ }^{8}$. Additionally, Sanders found that Type III fractures were not older than 9 years old 8 . In our study, it was observed that intra-articular fractures were common in both groups and became more common with increasing age. It was also observed that patients over 9 years old had Sanders Type III and Type IV fractures. We attribute the reason for this to our patients' exposure to high trauma.

In calcaneus fractures, it is necessary to achieve a stable anatomical reduction to prevent posttraumatic arthritis ${ }^{20}$. Petit et al $^{21}$ showed that children have high recovery abilities and low complication rates and good clinical results after surgical treatment. Pickle et al $^{6}$ reported the 30-month follow-up results of 7 immature calcaneus fracture patients treated with internal fixation ${ }^{5}$ of the patients had subtalar post-traumatic arthritis, and they did not see any other complications. In the literature, the study with the longest term result after ORIF is Ceccarelli et al7. The study, with a follow-up period of 12 to 53 years, has high functional scores (MFS> 88). However, they observed that subtalar joint arthritis occurred at an early grade. Tong et al. ${ }^{22}$ published the study with 25 pediatric calcaneus intra-articular fractures treated with open reduction with a minimally invasive sinus tarsi approach. They did not detect secondary arthrosis in their patients. Thermann et al. ${ }^{23}$ found posttraumatic arthritic in $65.2 \%$ of Sanders type II fractures and $81.7 \%$ of type III / IV. It is difficult to evaluate the Böhler and Gissane angles due to the high cartilage structure of the immature calcaneus ${ }^{17}$. During surgery, we were corrected to acceptable anatomical degrees. We achieved a stable anatomical reduction and no reduction loss. Approximately $75 \%$ of our patients had post-traumatic arthritis, and this rate was close to $100 \%$ of Type III and Type IV patients. In our opinion, as the fragmentation, cartilage damage and cancellous bone loss occurring during calcaneus fracture increase, the results worsen regardless of surgical treatment (open reduction internal plate fixation or closed reduction and percutaneous pinning).

Buckingham et al. ${ }^{24}$ found no wound problem or infection in their series of 9 immature calcaneus 
fractures treated with ORIF. Yu et al. ${ }^{25}$ detected a wound problem in 1 of the patients they treated with the lateral calcaneus plate. They treated with dressing. In our study, there was a superficial wound problem in 7 calcaneus. Patients were treated with antibiotics and daily dressings. Skin necrosis developed in 1 patient treated with plate and skin graft was applied.

One of the limitations of our study is that it is a retrospective study and it is problematic to access patient data. For this reason, the number of patients included in our study is low. A larger number of patient groups are required for statistically more reliable results. Another limitation is that the average follow-up period of our study is 81.5 months (range 12-156). We think that this period is sufficient, but we believe that it can be followed for a longer time for more robust results.

\section{CONCLUSION}

Immature calcaneus fractures are rare, and those without anatomical reduction, as in adults, have poor results. Sometimes the soft tissue around the fracture does not allow us to do the surgery we want. In pediatric calcaneus fractures, fragmentation due to the severity of trauma, cartilage damage, cancellous bone loss and their consequence may cause circulatory disorders between the fracture parts. As a result, post-traumatic arthritis may develop even if anatomical reduction is made. The most important thing that determines the result in pediatric calcaneus fractures is how high energy the fracture occurs rather than the surgical technique to be chosen.

Ethics Committee Approval: The study was approved by the Ethics Review Committee of our faculty (224/09.04.2021).

Declaration of Conflicting Interests: The authors declare that they have no conflict of interest.
Financial Disclosure: No financial support was received.

\section{REFERENCES}

1. Inokuchi $\mathrm{S}$, Usami $\mathrm{N}$, Hiraishi $\mathrm{E}$, Hashimoto $\mathrm{T}$. Calcaneal fractures in children. J Pediatr Orthop 1998; 18: 469-74.

2. Atilla P, Abdullah D, İbrahim A, et al. The effect of fracture type and angular deterioration on the functional outcome of calcaneal fractures. Dicle Tip Dergisi / Dicle Medical Journal 2011; 38: 35-9.

3. Crawford H. Rockwood and Wilkins in children. 7th ed. Lippincott Williams \&Wilkins; 2010. p. 1029-37

4. Ribbans WJ, Natarajan R, Alavala S. Pediatric foot fractures. Clin Orthop RelatRes 2005: 107-15.

5. Baker BI, Kinsman RG, Moss CA, et al. Structureactivity studies with fragments and analogous of salmonid melanin-concentrating hormone. Peptides 1990; 11: 1103-8.

6. Pickle A, Benaroch TE, Guy P, Harvey EJ. Clinical outcome of pediatric calcaneal fractures treated with open reduction and internal fixation. J Pediatr Orthop2004; 24: 178-80.

7. Ceccarelli F, Faldini C, Piras F, Giannini S. Surgical versus non-surgical treatmentof calcaneal fractures in children: a long-term results comparative study. FootAnkle Int 2000; 21: 825-32.

8. Benirschke SK, Kramer PA. Wound healing complications in closed and open calcaneal fractures. J Orthop Trauma 2004; 18: 1-6.

9. Brunet J. Calcaneal fractures in children. J Bone Joint Surg [Br]. 2000; 82: 211-6.

10. Mora S, Thordarson DB, Zionts LE, Reynolds RA. Pediatric calcaneal fractures. Foot Ankle Int 2001; 22: 471-7.

11. Schindler A, Mason DE, Allington NJ. Occult fracture of the calcaneus in toddlers. J Pediatr Orthop 1996; 16: 201-5.

12. Harvey E, Grujic L, Macey L. The incidence of morbidity associated with open reduction and rigid internal fixation of displaced intraarticular calcaneus fractures using a lateral approach. Foot Ankle Int. 2001; 22: 868- 73. 
13. Westhues $\mathrm{H}$ A new treatment method for the calcaneus fracture. Arch Orthop Unfallchir 1934; 35: 121.

14. Wondrak E Treatment of petrous bone fractures by internal Wxation. Zentralbl Chir 1959; 84: 260-6.

15. Sanders R. Current concept review. Displaced intra-articular fractures of the calcaneus. J Bone Joint Surg (Am) 2000; 82A: 225-50.

16. Kitaoka HB, Alexander IJ, Adelaar RS, et al. Clinical rating system for the ankle-hindfoot, midfoot, hallux, and lesser toes. FootAnkle Int 1994; 15: 349-53.

17. Schneidmueller D, Dietz HG, Kraus R, Marzı I. [Calcaneal fractures in childhood: a retrospective survey and literature review]. Unfallchirurg 2007; 110: 939-45. [Article in German].

18. Thomas HMK. Calcaneal fracture in childhood. $\mathrm{Br}$ J Surg 1969; 56: 664-6.

19. Summer H, Kramer AP, Benirschke SK. Pediatric calcaneal fractures. Orthop Rev2009; 1: 30-3.

20. Rammelt S, Schneiders W, Fitze G, Zwipp H. Foot and ankle fractures in children. Orthopade 2013; 42: 45-54.
21. Petit CJ, Lee BM, Kasser JR, Kocher MS. Operative treatment of intraar-ticular calcaneal fractures in the pediatric population. J Pediatr Orthop2007; 27: 856-62.

22. Lei T, Mingjing L, Fan L, Jian X, Tao H. A minimally invasive (sinus tarsi) approach with percutaneous $\mathrm{K}$-wires fixation for intra-articular calcaneal fractures in children.J Pediatr Orthop B. 2018; Nov;27: 556-62.

23. Thermann H, Hüfner T, Schratt HE, Albrecht K, Tscherne H. Treatment of intraarticular calcaneal fractures in adults. A treatment algorithm. Unfallchirurg1999; 102: 152-66.

24. Buckingham R, Jackson M, Atkins R. Calcaneal fractures in adolescents: CT classificationand results of operative treatment. Injury 2003 Jun,34: 454-9, 2003.

25. Yu GR, Zhao HM, Yang YF, Jia-Qian Z, Hai-Feng L. Open reduction and internal fixation of intraarticular calcaneal fractures in children. Orthopedics 2012, 35: e874-e879, 2012. 